The Japanese Journal of Psychology

1981, Vol. 51, No. 6, 310-317

\title{
五十音の順序判断にあらわれる心的機制の検討
}

\author{
日本大学 \\ 厳島行雄 ${ }^{1}$

\section{EXAMINATION OF MENTAL MECHANISMS UNDERLYING ORDER JUDGMENTS IN JAPANESE SYLLABARY}

\author{
YUKIO ITSUKUSHIMA
}

Department of Psychology, Nihon University

\begin{abstract}
To examine the underlying processes in the order judgments of Japanese syllabary, two experiments were conducted. In both experiments, subjects indicated by a binary motor response whether a pair of syllables were in proper order or not. In Experiment I syllables were paired in each row, and in Experiment II they were paired in each column of Japanese syllabary. Time to make such judgments was shorter for greater separation between two syllables (with the exception of Experiment I), and shorter for syllable pairs in proper order than for reversed order pairs. And depending on the conditions, serial position effect (SPE) showed varieties of patterns such as bowed SPE, monotonically increasing SPE, and disappearance of bowed SPE.
\end{abstract}

被験者に, 呈示される刺激の物理的属性ではなく, 刺 激によって指示される記憶表象の属性を比較判断させ, そのような判断に介在する心的機制を検討する研究が報 告されている。 心的比較 (mental comparison, Moyer \& Dumais, 1978) とか, 象徵比較 (symbolic comparison, Banks, 1977) と称せられる心的機能の研究であ る.

これらの研究では，まず判断すべき次元（もしくは記 憶表象の属性）が指定される.つぎにその次元上に位置 づ惊らる 2 項目が判断の対象として呈示される. 操作 される主な独立変数は次元上の項目間の隔り（必ずしも 物理的な長さや大きさではなく, 主観的大きさのように 評定された対象間の差という任意な尺度も含まれる), 判断の方向性, および次元上の項目の位置である. 従属 変数は判断に必要な時間 (以下判断時間と表記) とその 正確さである. 從来, 判断時間に 3 種の典型的効果が報 告されている. それらは, 判断次元上の 2 項目間の隔り の増大にともなう判断時間の減少を指寸象徵距離効果 (symbolic distance effect, 以下 SDE と略記, Moyer \& Bayer, 1976), 判断の方向性と項目の系列位置との 間任生起する交互作用を指す意味一致効果 (semantic congruity effect, 以下 SCE と略記, Banks, Fujii, \& Kayra-Stuart, 1976), および判断次元上の項目位置

1 本論文を作成するにあたり, 日本大学文理学部教授 浅井正昭, 妻倉昌太郎両先生に御指導いただきました。 ここに記して感謝いたします。
に対して得られる系列位置効果 (serial position effect, 以下 SPE と略記) である.

このような効果を報告する研究では，数の大小判断 (Banks et al., 1976 ; Buckley \& Gillman, 1974; Moyer \& Landauer, 1973 ; Parkman, 1971), 動物名を呈示し ての動物の大小判断 (Kerst \& Howard, 1977 ; Moyer,

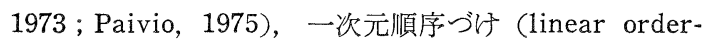
ing, Potts, 1972, 1974 ; Trabasso \& Riley, 1975), およびアルファベットの順序判断 (Lovelace \& Snodgrass, 1971 ; Parkman, 1971, Exp. III) などの課題が 用いられた。

ところで，SDEとSCE に関する限りはどの課題を用 いても比較的安定した結果が得られるが，SPEは課題や 実験手続に依存して 3 種のタイプが報告されている。そ れらは単調増加となる場合 (Fairbank, 1969), 単調減少 となる場合 (Moyer, 1973 ; Moyer \& Bayer, 1976), 抹 よび逆U字曲線となる場合 (Banks, 1977 ; Potts, 1974； Trabasso \& Riley, 1975) である.

上述の諸効果を生起させる心的比較の機制を統一的に 説明するために, Moyer \& Dumais (1978) は走査・比 較モデル (scan plus comparison model) を提唱し, Banks (1977) は離散符号化モデル (discrete coding model）を提唱している. 前者のモデルでは, SDEが， 弁別基準にいたる量情報の比較処理の反復回数によって 決定されると仮定するのに, 後者のモデルでは, 刺激対 が入力時に受ける処理符号の異同によって生じる弁別の 困難差によって決定されると仮定する.つまり, 同じ処 
理符号を受けたものは弁別が困難之考える．また，SCE に対して前者のモデルは, 自動打切型の走査が判断の方 向と一致した連続体上の端から行われた結果であると し, 後者のモデルは刺激の処理符号之教示符号の不一致 のために生起すると考光る. SPEに対しては両モデルと も明確な機制を提示していないが，逆U字の SPE につ いてはデータベースの構造に依存するとした.

以上のふたつのモデルは, 刺激の符号化処理が異なる ものの, 判断の基本的機制として符号化過程とそれにひ き続く弁別過程を仮定すること，就よび判断する項目が 位置づけられる内的表象が連続体として仮定されるとい 52 点で類似している.

ところで, 上述のふたつのモデルは心的比較に際し て, 量情報として処理される可能性のある課題の結果か ら推論される仮説的モデルであったが，アルファベット のように直観的には量情報へと变換されると考兄られな い順序情報の処理はどのように行われるのであろらか。

たとえば，Lovelace \& Snodgrass (1971) の順序判 断課題では SCE が生起しても, Banks (1977) や Moyer \& Dumais（1978）の指摘する典型的な交互作用ではな く, 系列の後半で順向判断 (Forward Judgment, 以下 FJ と略記) と逆向判断 (Backward Judgment, 以下 BJ と略記）の速さの差が消失するために生起するものであ る、また，FJはBJよりも常に速く行われるといら, 量 情報の判断課題では報告されない現象も生起している.

以上の 2 点を考慮すると, 量情報の心的比較と順序情報 の心的比較とでは異なる心的機制が介在すると予想され る.

そこで, 本研究では順序情報としての 50 音を材料と して, 50 音の順序判断に介在する心的機制を検討するこ とを目的とした. 50 音を検討対象に選択したのは，50音 がすでに体制化された知識であり，しかも母音と子音か ら構成された二次元的な規則的構造を持つと仮定される ので, 従来報告されてきた一次元的な情報構造を持つと 仮定される判断課題からの結果とは異なる結果が示唆さ れるためである。

具体的には，50音の行内音対 (実験 I) 拈よび段内音 対 (実験II) を用いた課題で上述の可能性を検討する。

$$
\text { 実 験 I }
$$

\section{方 法}

被験者 日本大学文理学部心理学料の学生 8 名.

実験材料と実験条件 50 音からヤ行 (以下読みの煩雑 さを避けるために音はカタカナで表記する), ラ行和よ びワ行を除いた音を刺激材料として使用した．この処理 は, ヤ行およびワ行の音がそれぞれア行の音と重複し, かつヤ行の削除により重複音を含まないラ行が孤立し, 段条件の均一化を妨げることによる. 50 音の残りの 7 行
内で同一音の組合わせを除き可能な音対を用意した。こ の操作によって各行20の音対が用意され, 20 対のらち 10 対は右から左へ読むと 50 音の系列に一致し ( $\mathrm{FJ}$ 条件), 残りの 10 対は逆の位置関係 (BJ 条件) となるように配 置した.

この組合わせにより各行内 4 種の音の隔り (step size, 以下 ss と略記）が用意される.ここで音対の左側に位 置する音を第 1 項目と決めて和くと， FJ 条件ではア段 から工段までの音が第1項に含まれる．BJ 条件では第 2 項目(右側に位置する音)に含まれる段音を段条件とす る. 以上の操作の結果, FJ, BJ 両条件をあわせて ss 1 が 56 対, ss 2 が 42 対, Ss 3 が 28 対および ss 4 が 14 対で合計 140 の試行が用意される。このように刺激を計 画することで，行と段に対するそれぞれの SPE と SCE， SS に対する SDE が検討可能である.

すべての音対は平仮名明朝体 1 号活字で白色紙に黒色 で印字した. 文字間の距離は $25 \mathrm{~mm}$ で, タキストスコ 一プの視野と文字対の中心が一致するよらに水平方向に 作成した.

実験手続 140 の文字対は 7 セッ（各セット内で $\mathrm{FJ}$ 条件, $\mathrm{BJ}$ 条件 10 試行ずつ）に分割し，それぞれの セット内で SS 1 から Ss 4 までが 8 対, 6 対, 4 対, 2 対となるようにランダムに割りあてた。 セット内での刺 激呈示順序および 7 セットの呈示順序は各被験者につき ランダムであった．第 1 セットの呈示に先行して本試行 に使用しない材料で 30 の練習試行を行ない, 課題の性 質を理解させた。

各試行は実験者の合図によって始まる．合図と同時に 凝視点が第 1 項目の提示される中央に 2 秒間呈示され る. 凝視点の消隇と同時に文字対が 2 秒間呈示される。 被験者の課題は呈示された文字対を第 1 項目から第 2 項 目への順序で, 2 つ文字位置が 50 音の順序と一致して いるか否かをできる限り速くかつ正確に判断することで ある.この判断は被験者の左右の手に持ったマイクロ・ スイッチで行われた. 判断のための FJ および BJ の手 は被験者間で相殺した。

実験装置 刺激は 3 視野タキストスコープ(竹井機器) によって提示し, 刺激呈示から判断までに必要な時間が タキストスコープに連結したタイムカウンタ(竹井機器) で測定された。反応は手押しのマイクロ・スイッチによ って行った。

\section{結 果}

詰反応 Table 1 K FJ, BJ 両条件の愦反応数および 誤反応率を各 SS 条件ごとに示した。全体の誤反応率は 9.5\% であった. FJ 条件の誤反応率は $7.5 \%$ であり, BJ 条件のそれは $11.4 \%$ であった. $\chi^{2}$ 検定の結果, FJ 条件と BJ 条件間で有意な差のある ss 条件はなかった が，Table 1 からも明らかなように ss が大きくなると 
TABLE 1

Percentage of incorrect judgments and number of errors (in parentheses) under $\mathrm{FJ}$ and $\mathrm{BJ}$ conditions in each step size condition (Exp. I)

\begin{tabular}{|c|c|c|c|c|c|}
\hline \multirow{2}{*}{$\begin{array}{l}\text { Direction } \\
\quad \text { of } \\
\text { judgment }\end{array}$} & \multicolumn{4}{|c|}{ Step size } & \multirow{2}{*}{ Total } \\
\hline & 1 & 2 & 3 & 4 & \\
\hline $\begin{array}{l}\text { Forward } \\
\text { judgment }\end{array}$ & $\begin{array}{l}8.5 \\
(19)\end{array}$ & $\begin{array}{r}7.7 \\
(13)\end{array}$ & $\begin{array}{c}8.0 \\
(9)\end{array}$ & $\begin{array}{c}1.8 \\
1\end{array}$ & $\begin{array}{r}7.5 \\
(42)\end{array}$ \\
\hline $\begin{array}{l}\text { Backward } \\
\text { judgment }\end{array}$ & $\begin{array}{l}13.8 \\
(31)\end{array}$ & $\begin{array}{l}10.7 \\
(18)\end{array}$ & $\begin{array}{r}8.9 \\
(10)\end{array}$ & $\begin{array}{r}8.9 \\
(5)\end{array}$ & $\begin{array}{l}11.4 \\
(64)\end{array}$ \\
\hline
\end{tabular}

誤反応率は減少する傾向にある。

判断時間 Fig. 1 には段条件別に行位置の関数として の FJ, BJ 両条件の平均判断時間, Fig. 2 には ss 条件 別に段位置の関数としての FJ, BJ 両条件の平均判断時 間を示した。

実験 I では各行条件に用意した ss の呈示確率が段条 件ごとに異なるので，それぞれの段条件別に 3 要因の分

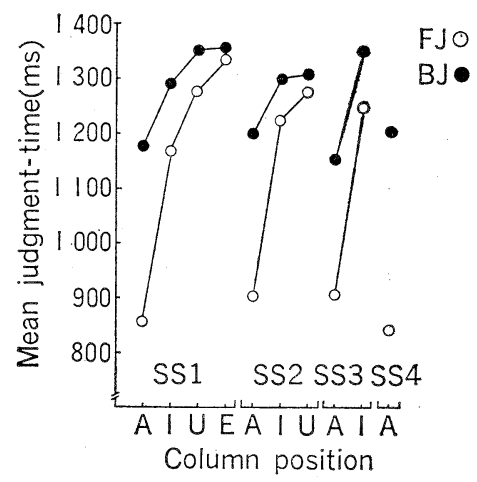

FIG. 2. Mean judgment-time as a function of serial position of column in each step size condition (Exp. I).
散分析 (判断 $\times \mathrm{ss} \times$ 行) を実施し，これらの要因の効果 を検討した。ただし，第 1 段条件の分析から第 4 段条件 の分析まで，SSの水準が 4 から 1 亿と変化するため，第 4 段条件の分析は 2 要因 (判断×行) であった。

分散分析の結果，第 1 段条件から第 3 段条件まで ss の主効果は認められなかった. 行の主効果はすべての分 析で有意であった（第 1 段条件から順に $F_{(6,55)}=9.59$, $p<.01 ; F_{(6,41)}=2.85, p<.05 ; F_{(6,27)}=8.67, p<.01 ;$ $\left.F_{(6,13)}=11.08, p<.01\right)$. 判断の主効果は第 1 , 第 2 段 条件の分析で有意であった $\left(F_{(1,55)}=210.72, p<.01\right.$; $\left.F_{(1,41)}=2.85, p<.05\right)$. 交互作用以第 4 段条件の分析に のみ認められた $\left(F_{(1,13)}=5.62, p<.01\right)$.

以上の結果から，段を固定した分散分析では（a)SDE が生起しないこと（Fig. 2)，(b) 行に対する SPEが認 められ，FJ条件では行に対して逆U字型の SPE，BJ 条 件では，第 2 段条件の逆U字型の SPEを除いて，注ぼ 単調増加の SPE であること (Fig. 1)，（c）第 1，第 2 段条件ではFJ がBJよりも速いこと（Fig. 1)，（d）第 4 段条件では行の前半 (ア行からナ行) で BJ が $\mathrm{FJ}$ よ りも速く, 後半でその関係が逆転すること(Fig. 1) が明 らかとなった。

つぎに，ssの条件に有意な主效果が認められないので 段条件を検討するために，各 SS 条件別に 3 要因の分散 分析 (判断 X行 $\times$ 段) を実施した. SS 1 条件の分析から ss 4 条件の分析で段要因の水準は 4 から 1 亿之変化する ので, ss 4 条件の分散分析は 2 要因 (判断×段)である.

分析の結果, ss 1 から ss 4 までの分析で判断の主効 果が認められた（SS1 から順に $F_{(1,55)}=20.04, p<.01$; $F_{(1,41)}=16.84, p<.01 ; F_{(1,27)}=58.88, p<.01 ; F_{(1,13)}$ $=5.22, p<.05)$. 行の主効果は ss 1 から ss 3 条件までの 分析で有意であった $\left(F_{(6,55)}=9.30, p<.01 ; F_{(6,41)}=\right.$ $\left.3.41, p<.01 ; F_{(6,27)}=5.01, p<.01\right)$. 段の効果は SS 1 からss 3 条件までの分析で有意であった $\left(F_{(3,53)}=23.17\right.$,

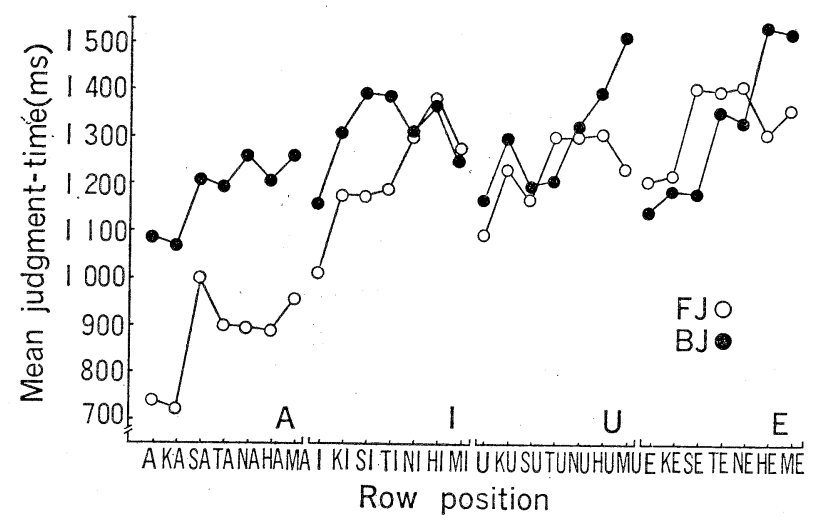

FIG. 1. Mean judgment-time as a function of serial position of row in each column condition (Exp. I). 
$\left.p<.01 ; F_{(2,41)}=21.73, p<.01 ; F_{(1,27)}=58.88, p<.01\right)$. また，交互作用は Ss 1 から ss 3 条件までの分析の判断 $\times$ 段で認めら机た $\left(F_{(3,55)}=3.93, p<.01 ; F_{(2,41)}=5.73\right.$, $\left.p<.01 ; F_{(1,27)}=4.96, p<.01\right)$.

以上の分析結果から，ss 条件を固定した分析では(a) FJはBJよりも速いこと (Fig. 2), (b) 行の進行に従 って判断が遅延すること (Fig. 1), (c) 段が進むと単調 增加の SPE があらわ礼るが，第 1 段を含むFJ は特に 速いこと (Fig. 2) が明らかとなった。

\section{考 察}

50 音の行内音対を用いた順序判断では $\mathrm{SDE}$ が見出せ なかった.この結果は量情報の判断課題や一次元順序づ け, アルファベットの順序判断課題の結果と一致しな い.アルファベットの順序判断課題で SDE を見出した Lovelace \& Snodgrass (1971) は, 呈示される2 項目の 系列上の隔りが大きければ, 系列の前部, 中部; 後部と いった位置に対する大采かな情報が利用できるために判 断の促進が可能であると解䄳する. この解积は Holyoak \&Walker (1976) の検討したカテゴリモデルに相当す るが，実騟 Iのように比較的短いss 条件では位置に対 するカテゴリ情報が利用できないため, SDE が生起しな からたという可能性も考光られる。つまり，50 音は行 単位で音之音位置が強く結合して和り，SDE を生起させ ないような順序判断機制が働くと推察される．また，梅 本・野村・近藤（1976）はプローブ法を用いた 50 音の 情報検索課題の結果から, 50 音の行単位の体制化の可能 性を示唆している.よって, 走査・比較モデルや離散符 号化モデルが仮定する升別処理は, 50 音の行内順序判断 には妥当しないと考光られる。

また，実験Iでは ss 条件に用意された刺激が ss 1 か らss 4 まで 4 対 3 対 2 対 1 の比率で呈示されている.この 呈示確率の差異が，同じ特性を持つ刺激の呈示確率が高 くなるとその刺激の同定時間が短くなるという Theios （1973）の指摘を考慮すると，ss 1 の判断時間を ss 4 の 判断時間倿近させたと解积できなくもない。しかし， Theios (1973) の研究が比較的単純な数字や文字の記憶 検索課題に限定されること, SDE は刺激の呈示確率に 影響されないという報告もなされていること (Moyer, 1973)，括よび 4000 試行の判断後でも SDE が消失し ないこと (Fairbank, 1969) を考觉ると，SS 条件の呈 示確率によって SDE が消失したといら解釈は困難であ る。

ところで，SPEについては行と段に対し，それぞれ特 有の傾向が認められた。行注するFJの SPE は各段 ごとにほ活逆 U 字型の傾向にあり, BJ では笏 2 段の逆 U字型の SPE を除いて単調増加の SPEであった. 逆U 字型の SPE は, 過去の研究では, 一次元順序づけ (Potts, 1974 ; Trabasso \& Riley, 1975; Woocher, Glass, \&
Holyoak，1978)の課題に生起する傾向があった．Potts （1974）は逆U字型のSPEが生じる理由として, 連続体 上の両端の項目の特殊処理を仮定しているが，Woocher et al., (1978) は Crowder (1976) の位置弁別性仮説 (positional discriminability hypothesis) 飞よって説明 できると主張する。この仮説は順序づけられた刺激が抽 象的, 空間的な内的配列を保つょう飞写像されること, 特よび中央の項目の位置弁別は両端の項目よりも困難で あることを仮定している。

このような仮定は判断汇介在する処理機制を定式化す るといらよりむしろ，貯蔵される情報の様式を定式化し ようとしたものと考光られる。 この仮定を採用するな ら, 50 音は学習時の入力形式を保ちながら 2 次元的に配 列された記憶表象を維持し, その結果 FJで逆U字型の SPE を生起せしめたと解釈できよう。しかしながら， BJ での単調増加の SPE は, 貯蔵される情報の様式を 反映せず，個々の音位置を継時的に弁別する機制が働く ことを示唆する（ただし，第 2 段条件のBJ に対する SPE は逆U字型であり性急な一般化はできない)，そし て, 本実験では, 50 音の順序判断といっても, ヤ行以 降の音を刺激から除いたといら制限を有するので, 実際 の 50 音の末端拈よび末端近い項目群が弁別容易であ るのか否かについて明言することはできない。

つぎに，段に対する SPE は FJ, BJ とも単調増加の SPEであった。乙かし，第1段を第1 項目に含を FJは 特に速い。この速い判断が判断 X段の交互作用の原因々 なっているが，これらの交互作用は離散符号化モデルが 示唆するよらな教示符号と次元上の項目位置とによって 生起する典型的な SCE とは考兄れない.というのは, BJ での最終段 (オ段) を含む条件で速い判断が見出せ ないためである.以上の段に対する SPE は，50 音の行 内音対の順序判断では第 1 段から処理が始まり, 音の含 まれる行位置が同定され，つぎに行内音を検索する処理 様式觉示唆する。

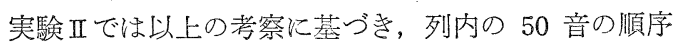
判断を実施し， 50 音の順序判断の機制をさらに検討す る.

\section{実 験 II}

\section{方 法}

被験者 実験 I に参加しなかった心理学専攻生 8 名.

実験材料之実験条件 ア段から才段までの各段内の 7 音を，同一音の組合わせを除いて，対にした。この操作 で各段とも FJ 21 対, BJ 21 対が用意された。全部で 210 対の刺激が用意された。これらの刺激のうち， ss 条 件はss 1 が 60 対, ss 2 が 50 対, ss 3 が 40 対, ss 4 が 30 対, ss 5 が 20 対, ss 6 が 10 対であった。 
TABLE 2

Percentage of incorrect judgments and number of errors (in parentheses) under $\mathrm{FJ}$ and BJ conditions in each step size condition (Exp. II)

\begin{tabular}{l|cccccc|c}
\hline $\begin{array}{l}\text { Direction } \\
\text { of } \\
\text { judgment }\end{array}$ & 1 & 2 & 3 & 4 & 5 & 6 & Total \\
\hline $\begin{array}{l}\text { Forward } \\
\text { judgment }\end{array}$ & $\begin{array}{r}7.1 \\
(17)\end{array}$ & 5.0 & 0.6 & 0.8 & 0.0 & 0.0 & 3.5 \\
\hline 10$)$ & 1 & $(1)$ & $(0)$ & $(0)$ & $(29)$ \\
\hline $\begin{array}{l}\text { Backward } \\
\text { judgment }\end{array}$ & 15.8 & 7.0 & 6.3 & 1.6 & 1.6 & 0.0 & 7.8 \\
$(38)$ & $(15)$ & $(10)$ & $(2)$ & $(1)$ & $(0)$ & $(66)$
\end{tabular}

実験手続 210 試行を 5 セットに分割し, 各セット内 で FJ が 21 対, BJ が 21 対となるようにした。 また， 各セット内で ss 1 から ss 6 までの条件がそれぞれ 12 対， 10 対， 8 対， 6 対， 4 対， 2 対となるようにランダ ムに抽出した。その他の手続はすべて実験 I と同様であ った.

結 果

誤反応 Table 2 に FJ, BJ 両条件の誤反応数扣よび 誤反応率を SS 条件別に示した. Table 2 からも明らか なように，Ss が大きくなると誤反応率は減少する傾向 が認められた。

判断時間 Fig. 3 には, ss 条件別に段位置の関数とし ての FJ, BJ 両条件の平均判断時間を示し, Fig. 4 には, 行条件別に ss の関数としての FJ, BJ 両条件の平均判 断時間を示した。

実験 IIでは，段条件に対して用意した SS の呈示確率 が行条件ごとに異なるので，行条件別に 3 要因の分散分 析 (判断×段 $\times S S$ ) を実施した. SS 要因の水準は第 1 行 条件の 6 から第 6 条件の 1 へと変化するので, 第 6 条件 の分散分析は 2 要因 (判断×段) であった.

分析の結果, 第 1 行条件では判断 $\left(F_{(1,59)}=228.27\right.$, $p<.01)$, 段 $\left(F_{(4,59)}=6.65, p<.01\right)$, ss $\left(F_{(5,59)}=6.10\right.$,

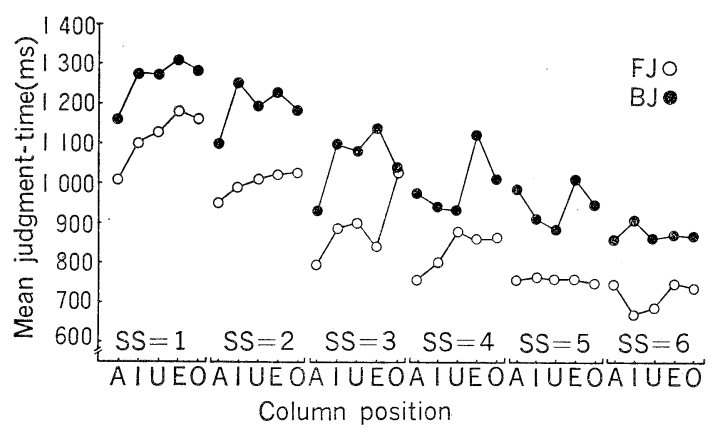

FIG. 3. Mean judgment-time as a function of serial position of column in each step size condition (Exp. II). $p<.01)$ の主効果, 和よび判断 $\times \mathrm{ss}\left(F_{(5,59)}=3.64, p<\right.$ .01）の交互作用が有意であった.

第 2 行条件の分析では, 判断 $\left(F_{(1,49)}=25.54, p<.01\right)$, SS $\left(F_{(4,49)}=2.33, p<.01\right)$ の主效果が有意であった.

第 3 行条件の分析では, 判断 $\left(F_{(1,39)}=16.76, p<.01\right)$, 段 $\left(F_{(4,39)}=5.47, p<.01\right)$ ，および ss $\left(F_{(3,39)}=12.86\right.$ ， $p<.01)$ の主効果が有意であった。

第 4 行条件の分析では, 判断 $\left(F_{(1,29)}=30.06, p<.01\right)$, 段 $\left(F_{(4,29)}=5.73, p<.01\right)$ の主効果, 特よび段 $\times \mathrm{SS}$ $\left(F_{(8,29)}=3.48, p<.01\right)$ の交互作用が有意であった.

第 5,6 行両条件の分析で有意な水準にある主効果叔 よび交互作用は認められなかった。

以上の結果から次の事実が明らかとなった。（ａ）第1 行から第 4 行条件で, FJ はBJ よりも速い(Fig. 4). (b)第 1 行から第 3 行までの条件で SDE が認められる (Fig. 4). (c)第 1，3，4 行条件の分析では段の主効果 が認められるが，これらをFig. 3 のように ss 条件別に みると, FJ で SS が小さい場合には単調増加の SPE, SS が大きくなるとフラットな SPEとなる. BJ で SS が 小さい場合は逆U字型の SPE となり, SS が大きくなる とフラットな状態に近づく。（d）第 1 行条件の分析で見 出された交互作用は，FJ が SSの影響を受けないのに 対し，BJ はssの影響を受け Ss が大きくなると速くな るために生起したと考学られる (Fig. 4). (e)第 4 行条 件の分析で見出された交互作用は, Ss 4 条件の FJ, BJ 両判断が急激に途延するが，その変動の違いによって生 起したものと考劣られる (Fig. 4). (f) Fig. 4 からも明 らかなように，行の進行に応じて判断時間が遅延する が，サ行，和よびタ行ではほぼ判断時間がー致している. しかし, 全体の傾向としては行に対しほぼ単調な SPE が得られたと言えよう。

\section{考 察}

段内の音対を用いた順序判断では，第 1 行条件から第 3 行条件で SDE が生起した. SDE が生起した原因とし

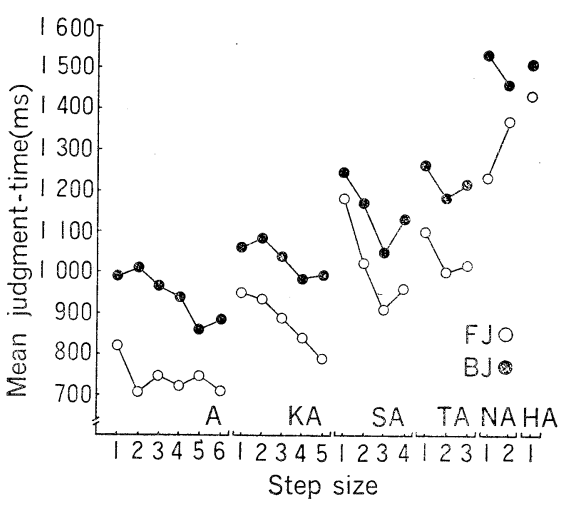

FIG. 4. Mean judgment-time as a function of step size in each row condition (Exp. II). 
て考台れるのは，（a）ss の大きさが実験Ｉよりも大 きかったこと，（b）Ss 条件の呈示確率が異なったこと， (c) 50 音に拈いては，行と段とで音と音位置の連合強 度が異なり，段は子音が音位置の弁別の手がかりになる ことなどの可能性である.（a）の可能性については，実 験 I と同様の SS の大きさでも SDE が生起することを 考慮すると, ss の大きさの差に原因を求めることは困難 であろら。また（b）の可能性についても，実験 Iの考 察で示したように呈示確率が影響するのであれば，実験 IIの結果として SS 1 から Ss 6 へと SDE が生起しない 方向で作用するはずである。しかし，そのよらな結果は 得られていない.SDE が生起したのは. 実験Iの考察で 示したように，段の体制化が行とは異なっていて（c)で 示唆するような貯蔵の様式を保っているためと推察され る.このことは実験 I と而の誤反応を比較すると明確で ある. 実験 I $\mathrm{FJ}$ 条件の誤反応率は実験IIのそれの 2.1 倍であり, BJ 条件では 1.5 倍であった.この実験 II 誤反応率の低下は, 段の音位置が行の音位置よりも 容易に弁別されることを示している．つまり，各行は 5 つの母音を単位に比較的強く体制化されているために, 行内音の位置弁別が困難であるのに対し，各段はひとつ の母音と異なる子音の組合わせによって体制化されてい るために，この子音が音位置の弁別性を高め，判断に対 して促進的に作用する可能性が示唆される.

ところで，実験Ｉ と同様実験II打いても FJ は BJ よりも速かった，そして，手続は異なるが，プローブ法 を用いた梅本他（1976）の50 音の検索課題，同様の手 続を用いた梅本・野村・湯川（1977）のアルファベット の検索課題でも順方向の逆方向に対する検索の優位性を 報告している．FJの BJ に対するこの優位性は，BJ に は第 1 項目音からの行 (もしくは段) 内の位置弁別にひ き続いて，第 2 項目音からの処理をするといら付加的機 制が要求されると仮定して拈いて，その処理の変換時間 と付加的処理に必要な時間とが FJ との差にあらわれた のではなかららか：このよらな解釈が可能な一方で，ア ルファベットの順序判断で同じ FJ の優位性を認めた Lovelace \& Snodgrass (1971) は，系列リストとして のアルファベットが位置情報と強く連合していて，その 位置情報が FJ を促進させるように機能すると解釈して いる. 以上のふたつの説明の可能性とは別に，梅本他 （1976）はFJ の BJ に対する優位性を Collins \& Loftus （1975）によって提唱された spreading-activation theory (活性化拡散理論) に検索の方向性の概念を導入する ことで説明できるとする可能性を示唆している．この説 明は，換言すれば，検索の方向性が異なれば，50 音の長 期記憶貯蔵位置への接近可能性が変化することを意味す ると考えられる。このような梅本らの説明は，たとえば Loftus（1973）のカテゴリ優位性とインスタンス優位性
を概念化した意味論記憶研究での，連合の方向性の違い による検索方略の問題と一脈通ずるものであろう.

これらの解釈のいずれが妥当するかは連合の強度和よ び方向性を制御した材料を用いた順序判断の研究が必要 となろら。

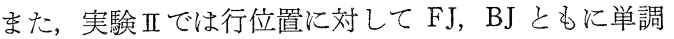
増加の SPE，段位置に対してはFJ で単調増加，BJで 逆U字の SPE であった。これらの結果は，実験Iにお いて行および段の位置に対して得られた SPE とは異な る. 実験 Iで得られた逆U字の SPE F FJ 条件であら

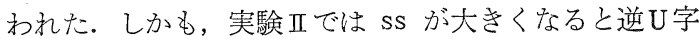
の SPE が消失する.このように行内音と段内音の順序 判断で異なる SPEを得たが，これらの結果に対しては， 単に 50 音の貯蔵情報に位置弁別性仮説を適用したり, 音の位置同定に継時処理や同時処理の概念を導入して説 明するのみならず，50 音の行と段の順序処理に和ける機 能的役割を一層検討する必要があろう.

さらに, 入力情報の表象様式, 50 音の表象様式, 入力 情報と貯蔵情報との照合過程を検討できる実験計画を用 意し, 本研究で得られた結果を統一的に説明できる原理 を求めなくてはならない。

\section{要 約}

本研究では, 50 音の順序判断に介在する心的機制を検 討するために，行内音対を用いた順序判断（実験Ｉ）拉

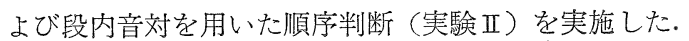
順序判断に影響すると予測される行位置, 段位置, SS, 判断の方向性の 4 変数が操作された. 従属変数は判断時 間叔よび判断の正確さであった。実験結果から次の結論 が得られた。

（1）従来の心的比較の研究で見出された SDE は, 実験 I の行内音対を用いた順序判断では見出せないが， 実験IIの段内音対を用いた順序判断には見出された。こ の結果から，行内音は母音中心の体制化が強固であり, この体制化が音位置の弁別に対して抑制的に作用する一 方，段内音は子音中心の体制化で，この子音情報が音位 置の弁別に対して促進的に作用する可能性が示唆された (Fig. 2 と Fig. 4).

（2） FJ 条件の第 1 段 (ア段) 音を含む音対は特に速 く判断された. このことは，50 音の順序判断では，ま ず第 1 段音から処理されることと同時に，第 1 段音が 50 音表象の末端に位置するという特殊性により, 位置弁別 も容易となった結果であると解釈された (Fig. 2).

（3）SPE に関しては，それぞれの条件に依存して 逆U字型の SPE, 単調増加の SPE, 逆U字型の SPEの 消失などが認められ, 従来の位置弁別性仮説や心的比較 の処理モデルによって説明することが困難であることが 示された. 50 音の順序判断に㘧ける位置の効果について 
は今後, 一層の検討が必要となろら。

(4) FJはBJ よりも速く判断された。この傾向は 音対の 50 音上の位置が前半にあるものほど顕著であっ たが，BJ のこの長い判断時間は，第 1 項目音からの処 理に引き続く第 2 項目音からの再処理を行うといら付加 的な処理の必要性に依存した結果として解釈された。

\section{引用文献}

Banks, W.P. 1977 Encoding and processing of symbolic information in comparative judgments. In G. H. Bower (Ed.), The psychology of learning and motivation Vol. 11. New York: Academic Press. Pp. 101-159.

Banks, W.P., Fujii, M., \& Kayra-Stuart, F. 1976 Semantic congruity effects in comparative judgments of magnitude of digits. Journal of Experimental Psychology: Human Perception and Performance, 2, 435-447.

Buckley, P. B., \& Gillman, C. B. 1974 Comparison of digits and dot patterns. Journal of Experimental Psychology, 103, 1131-1136.

Collins, A. M., \& Loftus, E.F. 1975 Spreading activation theory of semantic processing. Psychological Review, 82, 407-428.

Crowder, R.G. 1976 Principles of learning and memory. Hillsdale, N. J.: Lawrence Erlbaum Associates.

Fairbank, B. A., Jr. 1969 Experiments on the temporal aspects of number perception. Unpublished doctoral dissertation, University of Arizona.

Holyoak, K. J., \& Walker, J.H. 1976 Subjective magnitude information in semantic orderings. Journal of Verbal Learning and Verbal Behavior, 15, 287-299.

Kerst, S. M., \& Howard, J. H., Jr. 1977 Mental comparison for ordered information on abstract and concrete dimensions. Memory and Cognition, 5, 227-234.

Loftus, E.F. 1973 Category dominance, instance dominance and categorization time. Journal of Experimental Psychology, 97, 70-74.

Lovelace, E.A., \& Snodgrass, R.D. 1971 Decision times for alphabetic order of digit pairs. Journal of Experimental Psychology, 88, 258-264.

Moyer, R.S. 1973 Comparing objects in memory: Evidence suggesting an internal psychophysics.
Perception and Psychophysics, 13, 180-184.

Moyer, R.S., \& Bayer, R.H. 1976 Mental comparison and symbolic distance effect. Cognitive Psychology, 8, 228-246.

Moyer, R. S., \& Dumais, S. T. 1977 Mental comparison. In G. H. Bower (Ed.), The psychology of learning and motivation Vol. 12. New York: Academic Press. Pp. 117-155.

Moyer, R. S., \& Landauer, T. K. 1978 Determinants of reaction time for numerical inequality judg. ments. Bulletin of Psychonomic Society, 1, 167168.

Paivio, A. 1975 Perceptual comparison through the mind's eye. Memory and Cognition, 3, 635647.

Parkman, J.M. 1971 Temporal aspects of digits and letter inequality judgments. Journal of Experimental Psychology, 91, 191-205.

Potts, G. R. 1972 Information processing strategies used in the encoding of linear orderings. Journal of Verbal Learning and Verbal Behavior, 11, 727-740.

Potts, G. R. 1974 Storing and retrieving information about ordered relationships. Journal of Experimental Psychology, 103, 431-439.

Theios, J. 1973 Reaction time measurements in the study of memory process: Theory and data. In G. H. Bower (Ed.), The psychology of learning and motivation Vol. 7. New York: Academic Press. Pp. 43-85.

Trabasso, T., \& Riley, C. A. 1975 On the construction and use of representations involving linear order. In R. L. Solso (Ed.), Information processing and cognition: The Loyola Symposium. Hillsdale, N. J.: Lawrence Erlbaum Associates. Pp. 381-410.

梅本堯夫・野村幸正・近藤淑子 1976 知識体制の研究 (2) -50 音図の場合一 日本教育心理学会第 18 回 総会発表論文集, 494-495。

梅本瞢夫・野村幸正・湯川良三 1977 知識体制の研究 （3）ーアルファベットの場合一日本教育心理学会 第 19 回総会発表論文集, 330-331.

Woocher, F. D., Glass, A. L., \& Holyoak, K. J. 1978 Positional discriminability in linear orderings. Memory and Cognition, 6, 165-173. -1980. 3. 19. 受稿— 


\section{SUMMARY}

To examine mental mechanisms underlying order judgments of syllables in Japanese syllabary, two experiments were conducted. In Experiment I, syllables were paired in each row, and in Experiment II, they were paired in each column. Four independent variables were controlled; they were letter position in the row, letter position in the column, step size, and direction of judgment (which were considered to affect the judgments).

Main results and conclusion are as follows:

(1) SDEs which had been obtained in previous mental comparison researches were not found in Experiment I, but were found in Experiment II. These results suggested that rows in the Japanese syllabary were organized according to the five strong vowels, so that the organization made the discrimination of the position difficult; on the other hand, columns were organized according to their consonants, so that the consonants functioned to facilitate the discrimination (Figs. $2 \& 4$ ).
(2) FJ conditions which contained the first column syllables in the syllabary produced the fastest judgments. This suggested that in the order judgments of Japanese syllabary the first column syllables were processed first, and that the location of first column made the discrimination easy (Fig. 2).

(3) Depending the conditions, SPEs showed varieties of patterns such as orderly bowed SPE, monotonically increasing SPE, and disappearance of bowed SPE. These results are difficult to explain by the positional discriminability hypothesis or the information processing model of mental comparison previously proposed, and need further investigation for clarification.

(4) Pairs of syllables in FJ conditions were judged faster than those in BJ conditions. This trend was particularly marked for the former half of the syllabary. The inferiority of $\mathrm{BJ}$ to $\mathrm{FJ}$ may be explained by the extra processing necessary for the second item, following the processing of the first item. 